\title{
CALCIUM TRANSLOCATION IN THE AVIAN SHELL GLAND ( $\left.{ }^{1}\right)$
}

\author{
H. SCHRAER and Rosemary SCHRAER \\ Department of Biophysics, \\ Department of Biochemistry, \\ The Pennsylvania State University, \\ University Park, Pennsylvania 16802 (U.S.A.)
}

\section{INTRODUCTION}

As a model system for elucidating the process of cellular translocation of calcium, we have been studying the avian shell gland. 'This choice of experimental material was selected while we were engaged in the problem of the assessment of the mineral content of bone in live animals by quantitative radiography (SCHRAER, I966). Birds were of particular interest to us at that time because of the large changes in calcium metabolism that occurred during the reproductive cycle with the associated changes in medullary bone.

I would like to use this opportunity to review our recent work on the movement of calcium across the shell gland of the domestic hen and some of the steps which led to this area of study.

SKEIETAL RESPONSE, TO SHELL FORMATION OBSERVED " IN VIVO "

The interrelationship of the skeleton, calcium intake and egg shell formation san be profitably studied by the technique of quantitative radiography which has been described in other publications (SCHraER and SchraER, I96I; SchraEr, I966). In this procedure a standardized radiograph of a hen is taken in a prescribed manner for the quantitative assessment of the bone mineral content (fig. I). Analysis of the $\mathrm{X}$-ray film by densitometry at a preselected transverse trace path results in a value termed the $\mathrm{X}$-ray mass or bone mass coefficient. When in vivo $\mathrm{X}$-ray mass values of the center of tibia tarsus bones from several hens are compared with the dry-defatted

(1) Most of the work presented here was supported by Research Grants DE or 764 and AM 05970 from the National Institute of Health, the United States Public Health Service.

Annales de Biologie animale. - I970. 
weights of the same bone segments a correlation coefficient of 0.96 is obtained as shown in figure 2 .

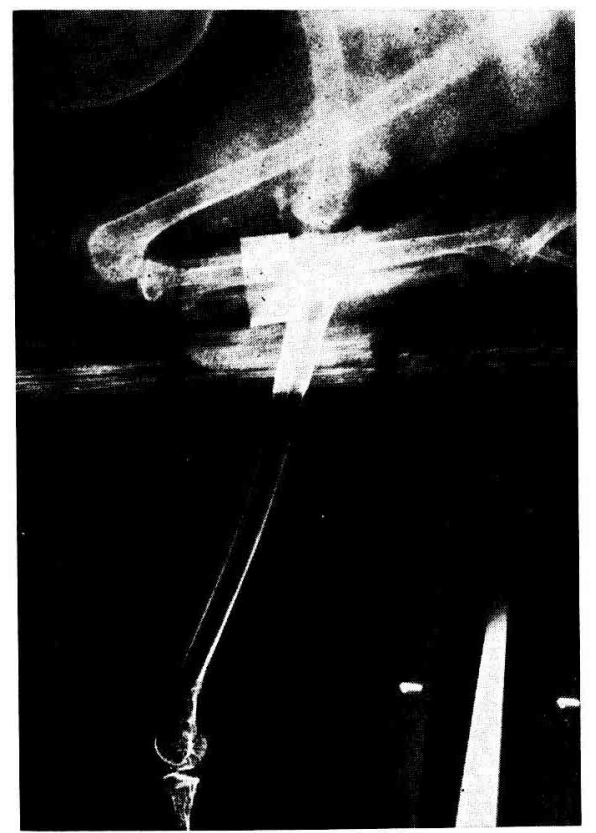

FIG. 1. - An X-ray film of a hen taken for bone mineral determination by densitometric analysis. The aluminum-zinc alloy wedge in the lower right corner serves as the standard. The center of the tibiotarsus is analyzed in a transverse direction between the two white dots. Note the egg in the upper left corner.

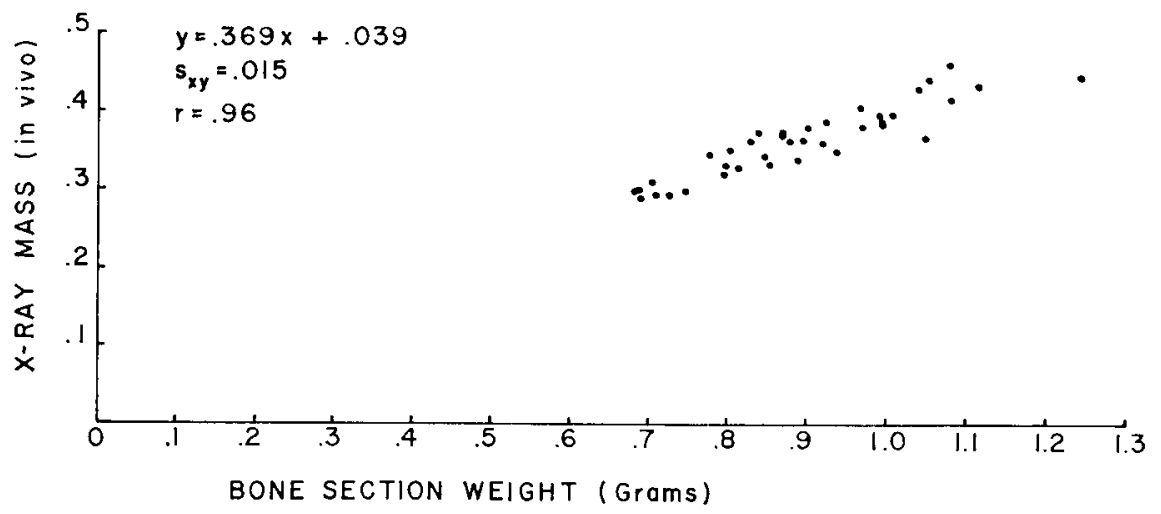

FIG. 2. - The relationship between the bone mass coefficient determined from the $\mathrm{X}-\mathrm{ray}$ film of the live hen and the weight of the same dry-defatted bone segment The regression equation and the correlation coefficient are shown

The X-ray technique was used to determine if the skeleton, as represented by the tibio-tarsus, showed cyclic changes during the egg-laying cycle (ScHraER and SchraER, I96I). In a histological study of the femurs of laying hens there was no 
clear relationship observed in the amount of medullary bone and the position of the egg in the reproductive tract (BLOOM et al., I958). The radiographic results did not contradict the histological findings, i.e. changes in $\mathrm{X}$-ray mass did not show cyclic changes which were in phase with shell formation. A repeat of this experiment with ten pullets X-rayed every four hours for 96 hours gave the same results. Although several normal eggs were deposited during this time the bone mass changes did not reflect the fact that a shell was being formed. What did emerge was that hens which laid the most eggs (5) had the lowest average bone mass value while those that deposited the fewest eggs (3) had higher values. These data are shown in table I. It is possible that in the high producers the calcium reserves were depleted due to the demands of calcium for shell formation as suggested by HURWITz and GRIMINGER (I960).

\section{TABLE I}

The relationship of the bone mass coefficient of a central tranverse segment of a central transverse segment of the tibio-tarsus and the number of shelled eggs laid during a 4-day period

The standard deviations are shown with the bone mass values

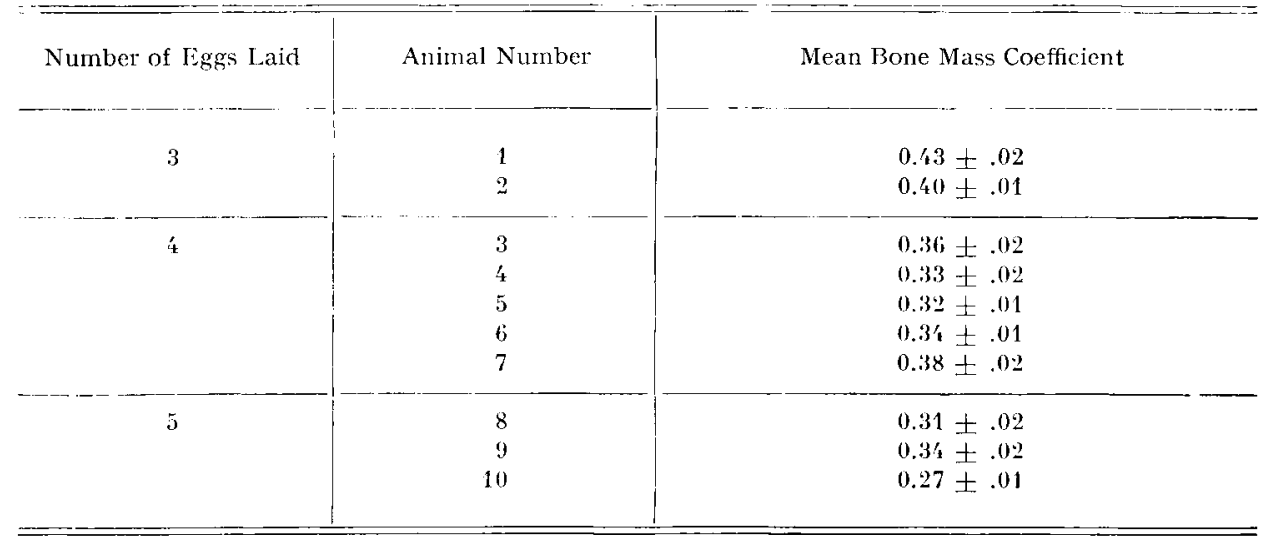

Withholding the calcium from the diet of laying hens causes a rapid drain on the skeletal stores of bone mineral since egg laying continues for several days with this treatment and the only source of calcium is the skeleton. To illustrate this response, 20 laying hens were placed on a low calcium ration and radiographed for X-ray densitometry each day for I I days. By the third day some of the hens started to lay soft shelled eggs and all had ceased laying by the ninth day. The mean bone mass coefficient of the twenty hens was plotted against the number of days on the low calcium diet as shown in figure 3 . A decided drop in bone mass coefficient was observed after one day of treatment. The rate of bone mass decrease was rapid for the first 4 or 5 days and then slowed down in keeping with the decrease in shell formation. On the ninth day of the experiment each bird was force-fed 5 grams of calcium carbonate with a resultant increase in bone mass coefficient.

The reproductive cycle of pigeons differs from that of the domestic fowl which lays eggs almost continuously over an extended period of time. Pigeons normally lay a two-egg clutch and if the eggs are removed they will lay another clutch in 


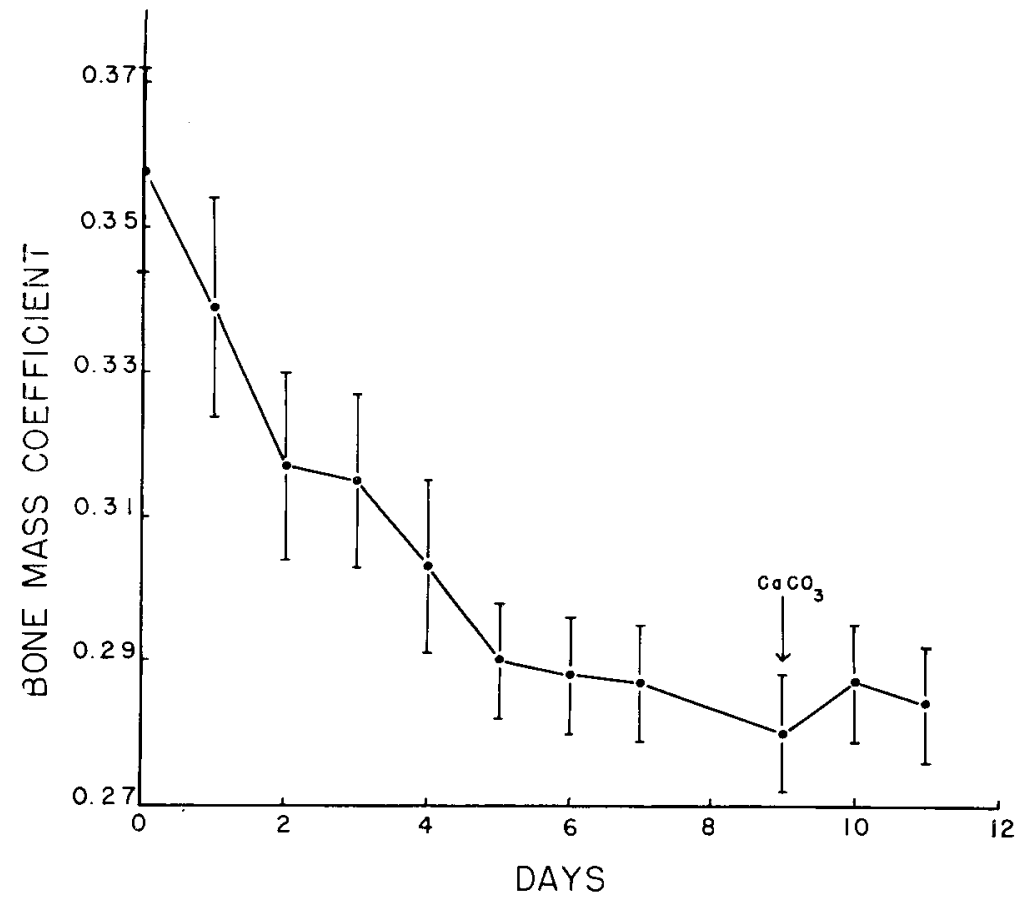

FIG. 3. - Bone mass change of the tibio-tarsus of laying hens maintained on a low calcium diet Calcium carbonate $(5 \mathrm{~g})$ was force-fed to each hen on the ninth day

\section{Pre-Ovulation|Ovulation|Post-Ovulation}
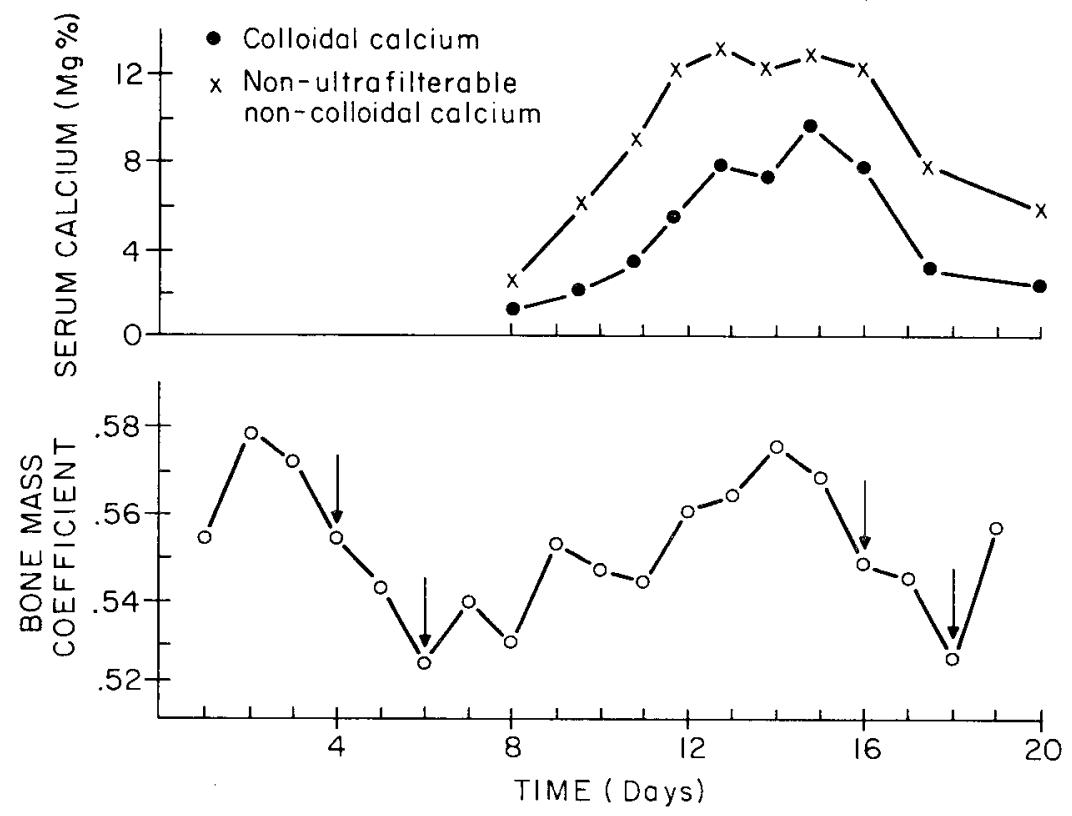

FIG. 4. - The changes in tibio-tarsus mass of pigeons during the laying cycle

An X-ray film was taken each day of the study. Eggs were laid at the points indicated by arrows. The blood calcium levels of MCDonALD and RiDDie (I945) are shown in the upper part. 
about ten days. During this time medullary bone formation occurs in preparation for the shell formation which is to follow. This interesting skeletal response to the physiological state of the ovary has been known for some time (KYES and POTTER, I934). In the following account radiographic observations on living pigeons were made which demonstrate this phenomenon clearly.

$\mathrm{X}$-ray bone mass data were collected daily for five laying pigeons. The same $\mathrm{X}$-ray procedure was used as for the domestic fowl. The data for each bird were arranged so that the cycles were in phase with each other. The composite picture thus formed is shown in figure 4 . Note the rhythmic rise and fall in bone mass coefficient in association with the phase of the reproductive cycle. The mass coefficient values are highest just prior to shell formation and fall as the shell is deposited. After the second egg of the clutch is deposited the bone mass coefficient begins to increase. The serum calcium data from a paper by MCDONALD and RIDDIE (I945) are included in the figure and are coherent with the bone mass data.

The skeletal response of the two avian types studied, the domestic hen and the pigeon, representing different modes of laying cycles is clearly shown by quantitative radiography.

\section{CHANGES IN CALCIUM CONTENT}

\section{OF THE OVIDUCT WITH THE EGG-LAYING CYCLE}

Consideration of these data stimulated our interest in the cellular mechanisms involved in the translocation of such large quantities of calcium in a defined period of time. We thought that investigation of the shell gland which represents a highly amplified system of calcium transport might provide information which would be of general application to calcium transport theory. A study was performed to observe the pattern of the tissue content of calcium and certain other metals in the functional segments of the hen's oviduct (SchraER and SchraER, I965). Animals were decapitated, the oviducts were removed and the position of the egg in the oviduct was noted. The oviduct was cut into sections corresponding to the magnum, isthmus and shell gland. The segments were lyophylized, weighed and ashed at $500^{\circ} \mathrm{C}$ for 5 hours. Analysis for several metals including calcium were performed by emission spectroscopy. Table 2 shows the calcium content of the different segments and the change in cal-

TABLE 2

Calcium content ( $\mathrm{mg} / \mathrm{g}$ ash) of oviduct segments in relation to egg location at time of sacrifice

The values are presented as means \pm standard essors. (From Schraer and Schraer, I965)

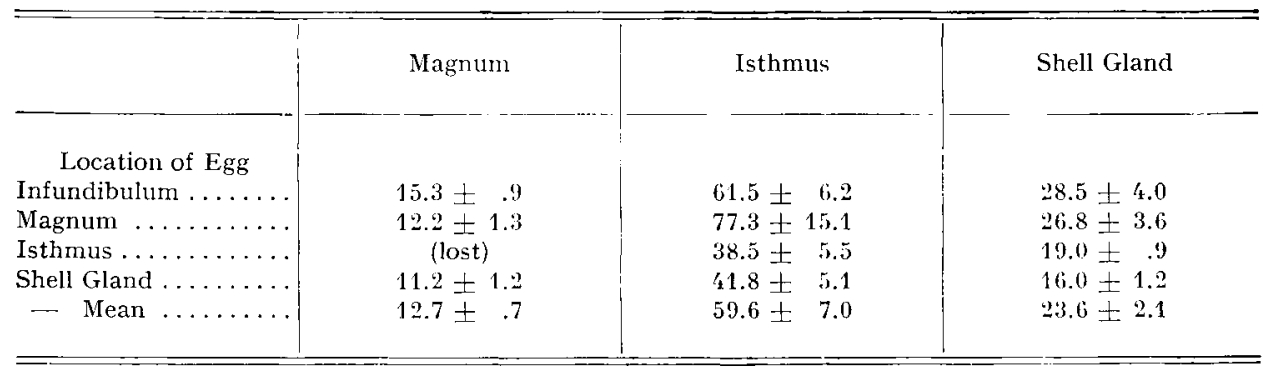


cium content as the egg moves through the oviduct. Note that the highest values are for the isthmus regardless of the location of the egg. High isthmus values have also been observed by TAYLOR and HERTELENDY (I960) and by MISRA and KEMÉNY (I964). Highest values for the isthmus were found when the egg was in the infundibulum $(6 \mathrm{I} .5 \pm 6.2 \mathrm{mg} / \mathrm{g}$ ash) and the magnum $(77.3 \pm \mathrm{I} 5 . \mathrm{I} \mathrm{mg} / \mathrm{g}$ ash). The lowest value occurred when the egg was in the isthmus $(38.5 \pm 5.5 \mathrm{mg} / \mathrm{g}$ ash). The values for the shell gland, which were about half that of the isthmus, also indicated that an outward movement of calcium occurs when a shell is being formed. The magnitude of the differences for the shell gland is not high although they are significant. In relation to the total quantity of calcium that moves through the shell gland these quantities are not significant.

\section{CALCIUM MOVEMENT ACROSS THE ISOLATED SHELI, GLAND}

More recently we have utilized an in vitro preparation of the shell gland in an attempt to observe some metabolic aspects of calcium movement in a controlled environment (EHRENSPECK et al., I967). The preparation employed is diagrammed in figure 5. A piece of tissue about $2 \mathrm{~cm}$ in diameter was taken from the mid portion of the shell gland and stretched over a tube so that the tissue served as a membrane for the separation of two fluid compartments. The fluid of the reservoirs served simultaneously as an incubation medium and as a source for sampling to assay the direction and quantity of calcium movement when ${ }^{45} \mathrm{Ca}$ was used as a tracer. Unidirectional fluxes between serosa and mucosa were measured and subsequently net directional fluxes were calculated. A net flux of calcium was measured in the mucosal direction which was more than twice the value when the donor hen was in

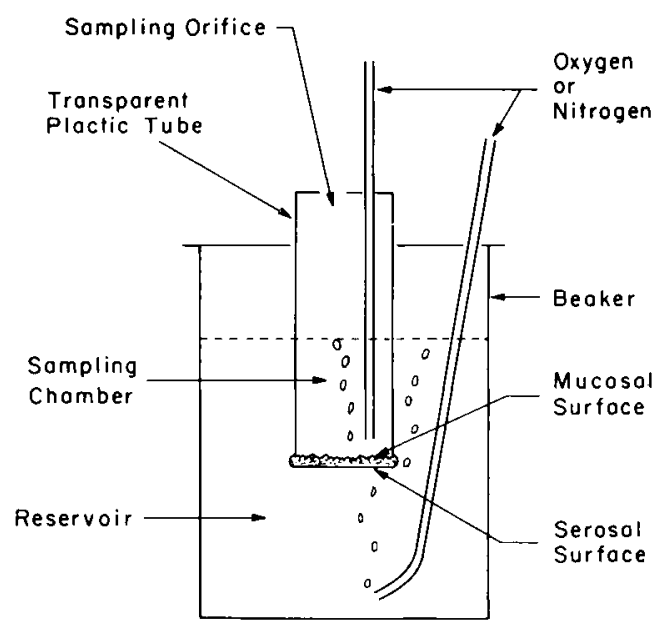

FIG. 5. - The apparatus used for determining the unidirectional fluxes of ${ }^{45} \mathrm{Ca}$ in the shell gland in vitro

The temperature is maintained at $39.5^{\circ} \mathrm{C}$ and ${ }^{45} \mathrm{Ca}$ is added to the incubation medium in the reservoir. The tissue in the diagram is arranged to observe ${ }^{45} \mathrm{Ca}$ flux from the serosa to the mucosa. Flux ratios are measured by inverting one of a pair of tissue pieces cut from the same shell gland and determining the flux in both of them. (From EHRENSPECK $e t$ al., I 967 ). 
the process of shell formation when compared with donors that did not have an egg in the shell gland.

The effect of various chemical and physical conditions on ${ }^{45} \mathrm{Ca}$ movement in this system was also studied and the results are shown in figure 6 . Net transfer of calcium to the mucosal or luminal side of the membrane system was dependent upon an oxidizable substrate, such as sodium succinate and was markedly decreased by additions to the membrane incubation medium of such inhibitors as potassium cyanide, 2,4 dinitrophenol and a nitrogen atmosphere. The conclusion from this experiment was that calcium movement across the avian shell gland in vitro is dependent, at least in part, upon metabolic energy derived from oxidative metabolism.

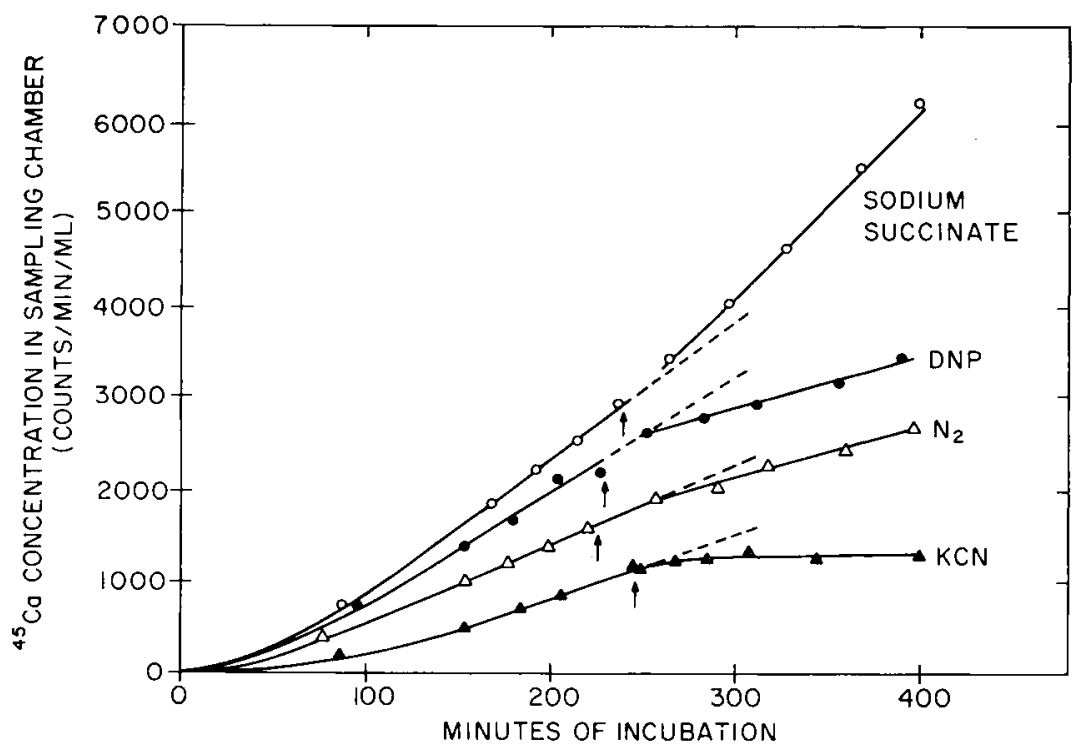

FIG. 6. - The effect of various substances on the response of ${ }^{25} \mathrm{Ca}$ movement from serosa to mucosa

Different animals were used in each case, and the curves were selected to prevent overlay. Initiation of treatment is indicated by the arrows (From EHRENSPEck et al., 1967).

In a similar incubation system in the form of two Ussing-type cells (Ussing and ZERAHN, I95I), transmural membrane potentials of this preparation were measured (EHRENSPECK and SCHRAER, I968). In these preliminary experiments conditions were identical with those used in the previous study. Calcium concentration was I. 8 millimoles per liter and was the same on both sides of the membrane. The meastrement of electrical properties of this tissue in vitro showed a potential difference of about I millivolt. The intermittent short circuit current profile had a value of about 25 microamperes.

The curve for ${ }^{45} \mathrm{Ca}$ movement from serosa to mucosa had the typical initial lag and final steady-state rate previously observed. The initiation of a continuous measurement of short circuit current which causes a small drop in potential and short circuit current did not affect ${ }^{45} \mathrm{Ca}$ movement. Even though the magnitude of the potential was small, the mucosa was always negative with respect to the serosa. The application of Ussing's equation (UsSING and ZERAHN, I95I) for passive ion trans- 
port showed that the magnitude of the observed potential difference was much too small to explain the calcium flux ratio of 2.4 found in the earlier experiments. With such a flux ratio (2.4) the potential should be about I 2 millivolts. Thus, the membrane potential appears not to be directly involved in the movement of calcium across the shell gland in vitro. These data, and those indicating a dependency of calcium movement on oxidative metabolism, suggest the existence of an active calcium transport mechanism.

The effect of acetazolamide, a specific inhibitor of carbonic anhydrase (MIANN and KEIIIN, I940), was studied using the method shown in figure 6. Sampling was not begun until after the system had reached a steady state. Acetazolamide administered on both sides of the membrane to a final concentration of $0.05 \mathrm{M}$ resulted in an increase in both unidirectional ${ }^{45} \mathrm{Ca}$ fluxes. The ratio of the slopes of the curves before, 2.53, and after, 2.I2, acetazolamide treatment, however, were not significantly different. The unidirectional fluxes were increased by acetazolamide, but the net movement of ${ }^{45} \mathrm{Ca}$ was not changed.

The experiment demonstrates that the tissue responds to the drug in iitro. The question of how these results fit into the picture of inhibition of shell formation by acetazolamide in vivo is not answered by these preliminary data. It appears that net calcium movement into the lumen in the isolated system does not depend on bicarbonate production. Further experimentation has to be done with this system to establish the significance of these results.

\section{AUTORADIOGRAPHY OF CALCIUM IN THE MUCOSA}

The goal in this study was to localize the cells or cell type(s) that constitute the major route of calcium translocation (GAY and ScHRAER, I967; GAY and SCHRAER, I969). Autoradiography using ${ }^{45} \mathrm{Ca}$ was the technique employed since we wished to see the calcium that was being moved rather than the constitutive calcium which would be revealed by histochemistry.

Freeze-substitution (FEDER and SIDMAN, I958), was used in order to retain as much as possible of the easily ionized calcium which is lost in tissue prepared for histochemistry. Regularly laying White Leghorn and Comet Hens were selected for each experiment according to the position of the egg in the oviduct.

In the in vitro experiments blocks of shell gland mucosa $2 \mathrm{~mm}$ square were immersed in Io $\mathrm{ml}$ of a tris buffered incubation medium (TAYLOR and WASSERMAN, I965) which contained IOO $\mu \mathrm{c}$ of ${ }^{45} \mathrm{Ca}$. Tissues were incubated at $0^{\circ} \mathrm{C}$ and $42^{\circ} \mathrm{C}$ with and without $5 \times \mathrm{IO}^{-4} \mathrm{M} \mathrm{2,4-dinitrophenol} \mathrm{(DNP).} \mathrm{Tissue} \mathrm{was} \mathrm{removed} \mathrm{from} \mathrm{the} \mathrm{incuba-}$ tion medium at $I$ and Io minutes, rinsed in the salt solution to remove surface calcium and processed by freeze-substitution. In in vivo experiments, ${ }^{45} \mathrm{Ca}$ was injected into the brachial vein of four hens, each of which received $5 \mathrm{mc}{ }^{45} \mathrm{Ca}$ in $\mathrm{I} \mathrm{ml}$ of distilled water. The birds were decapitated 5 minutes later and samples were removed from the shell gland, isthmus and magnum.

The columnar cells accumulated considerably more ${ }^{45} \mathrm{Ca}$ than the tubular gland cells under all conditions studied. A phase contrast autoradiograph (fig. 7) of the shell gland mucosa which was exposed in vitro for Io minutes at $0^{\circ} \mathrm{C}$ shows that the grains 
predominate over the columnar cells. When ${ }^{45} \mathrm{Ca}$ was given intravenously, there were again more grains over the columnar cells than over the tubular gland cells. The grain counts for each segment of the oviduct considered in relation to the position of the egg are shown in table 3. The columnar cells had the highest counts in any case, but equally important was the finding that when a shell was being formed

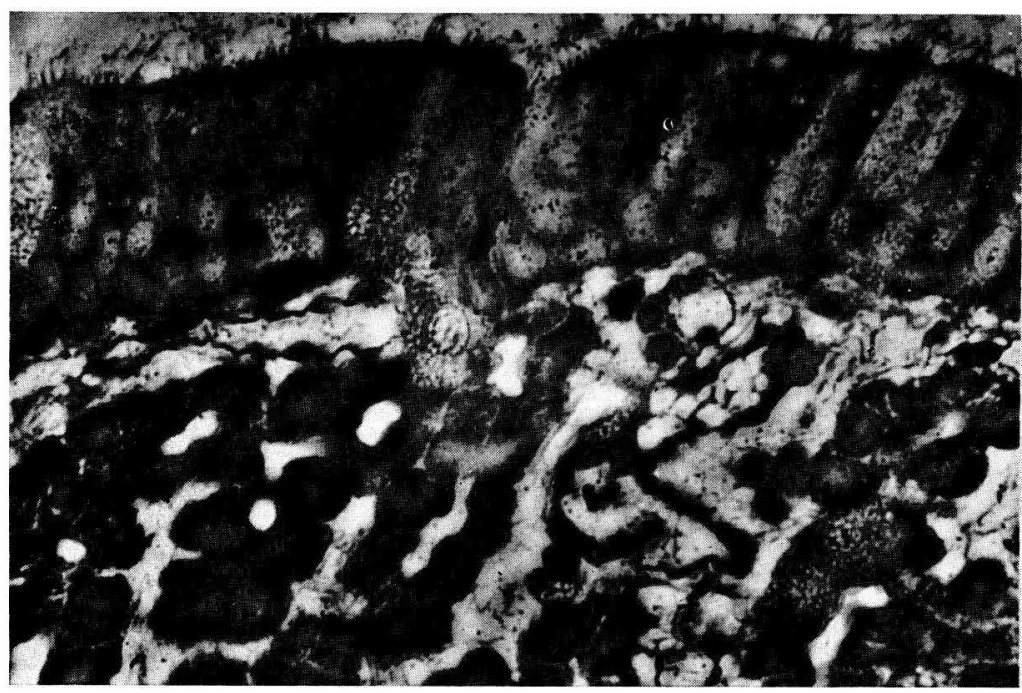

Fig. 7. - Autoradiograph of the shell gland mucosa

The tissue was incubated in a ${ }^{45} \mathrm{Ca}$-containing medium for 10 minutes at $0^{\circ} \mathrm{C}$. The grains are predominantly over the ciliated and non-ciliated columnar cells. X 630.

TABI,E 3

Mean grain counts of autoradiographs of tissue in hen given 45 Ca intravenously. Each field was Iooo square microns.

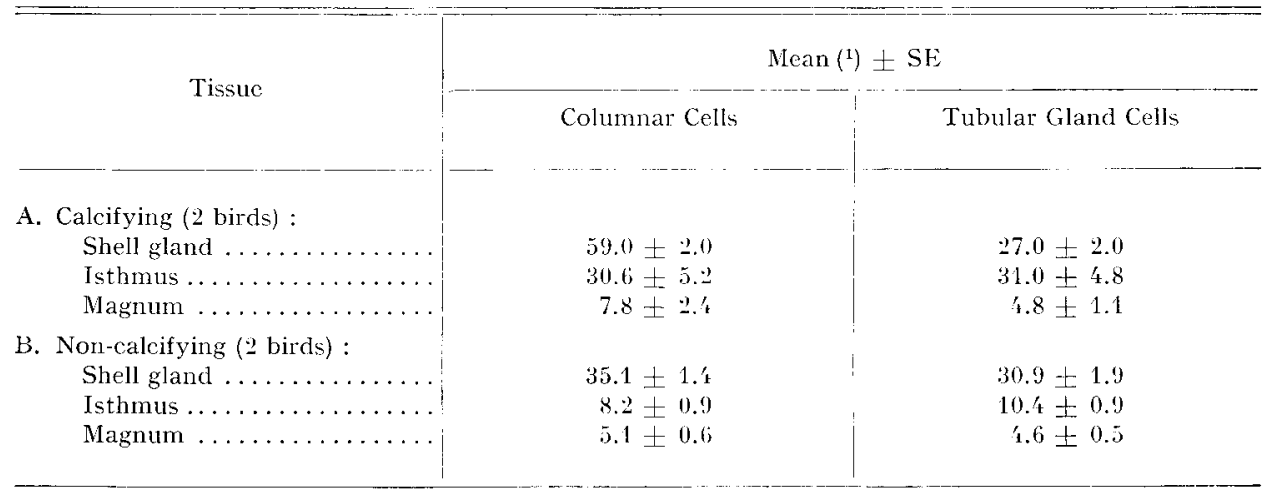

( ${ }^{1}$ Grain counts of 50 microscopic fields.

the grain counts were twice as high in these cells $(59.0 \pm 2.0)$ than when there was no egg in the shell gland (35.I \pm I.4). The tubular gland cells showed no change. 
Grain counts for the isthmus and magnum followed the same pattern in each state, but the isthmus values were much higher when a shell was calcifying.

The results of incubation experiments are summarized in figure 8 . It can be seen that : (I) Columnar cells took up ${ }^{45} \mathrm{Ca}$ in proportion to the time spent in the incubation medium. This occurred at $0^{\circ} \mathrm{C}(\mathrm{A}$ vs $\mathrm{C}, \mathrm{P}<.05)$, at $42^{\circ} \mathrm{C}(\mathrm{B}$ vs $\mathrm{D}, \mathrm{P}<.05)$,

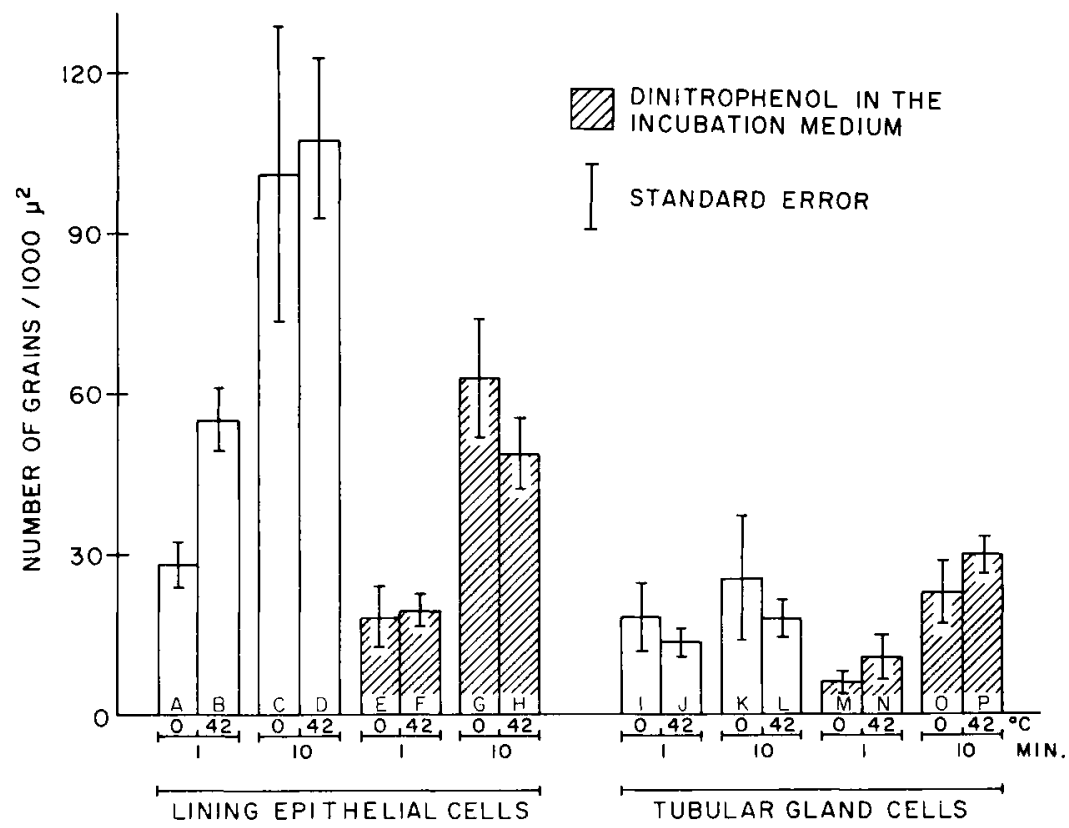

FIG. 8. - Grain counts of autoradiographs of the shell gland mucosa

Pieces of tissue were incubated in a mediun that contained ${ }^{45} \mathrm{Ca}$ for one and ten minutes, and at $0^{\circ} \mathrm{C}$ and $42^{\circ} \mathrm{C}$. In some cases 2,4 dinitrophenol was added to the medium. The bars which are identified by the letters $A$ to $P$ are described in the text. Each bar is the mean of 30 microscopic field. (From GAY and SCHRAER, I969).

and in the presence of DNP (E vs G, P <. 05, F vs. H, P <.05). (2) The increase in temperature significantly increased the amount of ${ }^{45} \mathrm{Ca}$ accumulated by columnar cells in one minute $(\mathrm{A}$ vs $\mathrm{B}, \mathrm{P}<.05)$. The increase was not significant for the Io minute treatment (C vs. D). Temperature had no effect when DNP was present ( $E$ vs $F$, and $\mathrm{G}$ vs $\mathrm{H}$ ). (3) Treatment with DNP significantly depressed the amount of ${ }^{45} \mathrm{Ca}$ accumulated by columnar cells at $42^{\circ} \mathrm{C}$ ( $\mathrm{B}$ vs $\mathrm{F}, \mathrm{P}<$. OI, and $\mathrm{D}$ vs $\mathrm{H}, \mathrm{P}<.05$ ), but not at $0^{\circ} \mathrm{C}$ (A vs E and C vs G). (4) The gland cells were not significantly affected by changing these parameters.

The results of this group of experiments show that the columnar epithelial cells of the shell gland mucosa have a greater affinity for ${ }^{45} \mathrm{Ca}$ than the tubular gland cells and are probably the cells most directly involved in the movement of calcium to the lumen of the oviduct after leaving the capillaries. 


\section{CALCIUM DISTRIBUTION IN CELI, FRACTIONS \\ OF THE, SHEI, GLAND MUCOSA}

There is a large body of literature on distribution of metal ions in subcellular fractions of different tissues (ThIERs and VALLEE, I957; Cosmos, I964). The mitochondria have been implicated as intracellular sites of calcium accumulation, and since the shell gland moves large quantities of this metal, it seemed an ideal tissue to investigate the association of mitochondria and calcium transport. The detailed procedures of the work reported here have been published earlier (HoHMan and SCHRAER, I966).

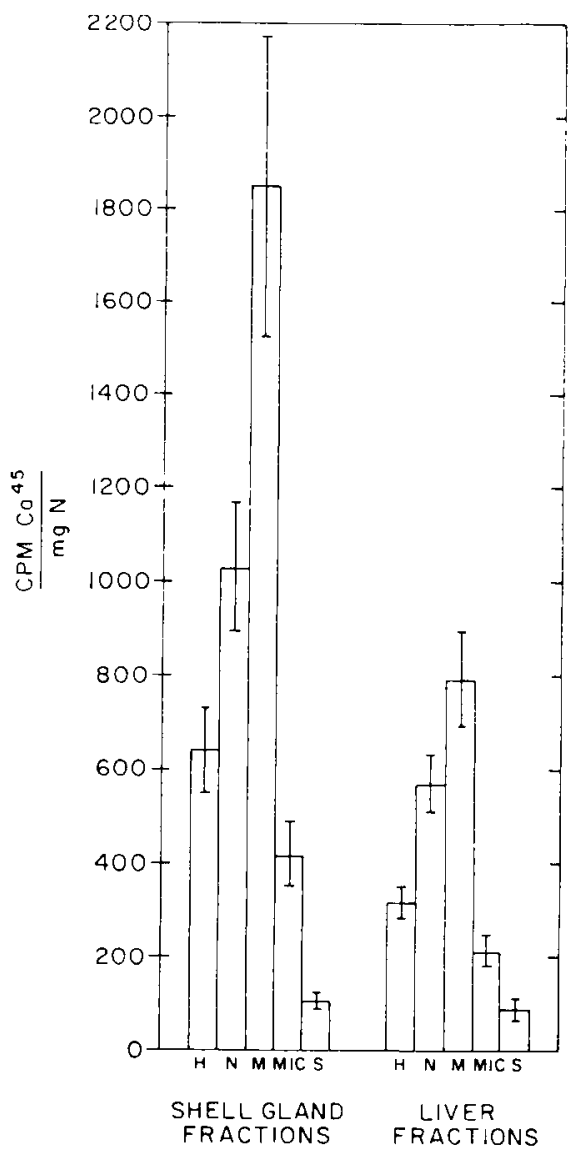

FIG. 9. - The distribution of ${ }^{45} \mathrm{Ca}$ in $C P M / m g \mathrm{~N}$ in the cell fractions of the shell gland mucosa and liver

Nine animals were used for the shell gland and six for the liver. Standard errors are indicated. $\mathrm{H}$, total homogenate; $\mathrm{N}$, nuclear fraction ; M, mitochondrial fraction ; Mic, microsomal fraction ; S, supernatant fraction. (From HoHMAN and SchRAER, I966).

When cell fractions of the shell gland mucosa and liver of the same animals were prepared from laying hens given ${ }^{45} \mathrm{Ca}$ intravenously and decapitated 5 minutes later, the radionuclide was distributed as shown in figure 9 . In both tissues, the mitochondria 
showed the highest values expressed as counts per minute of ${ }^{45} \mathrm{Ca}$ per $\mathrm{mg}$ nitrogen $\left(\mathrm{CPM}{ }^{45} \mathrm{Ca} / \mathrm{mg} \mathrm{N}\right)$. The nuclear fraction was next followed by the microsomal and supernatant fractions. It is important to note however that the mitochondrial fraction of the shell gland had disproportionately higher values when compared to the liver. The ratio of shell gland to liver values was 2.32 for the mitochondria, I.8I for the nuclei, I.94 for the microsomes, and I.I 5 for the supernatant. In addition, the ratio of each fraction to the total homogenate for each tissue was highest for the shell gland mitochondria.

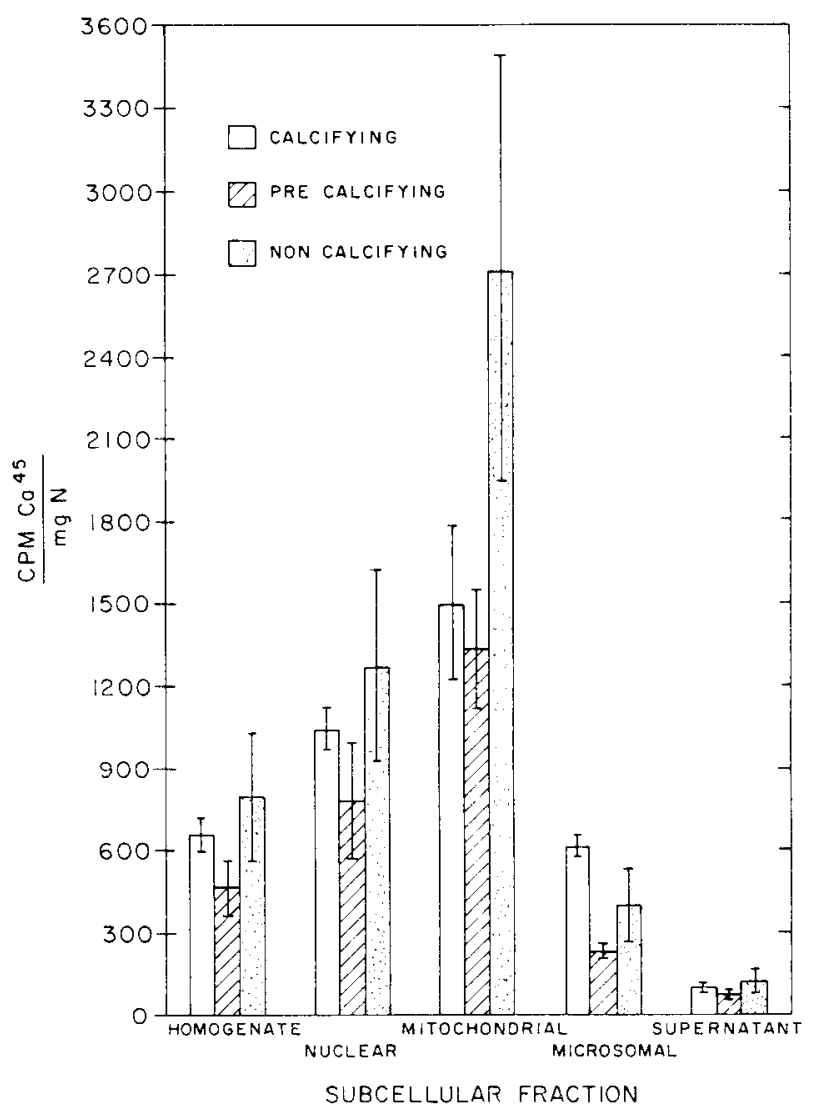

FIG. Io. - The distribution of $C P M{ }^{45} \mathrm{Ca} / \mathrm{mg}_{\mathrm{N}} \mathrm{N}$ in the cell fractions of the shell gland mucosa according to its physiological activity at the time of sacrifice

Three animals were used for each physiological state : calcifying, pre-calcifying or isthmus egg, and noncalcifying or no egg in the oviduct. Standard errors are indicated. (From Hohman and SchraEr, I966).

The data for the shell gland mucosa are interesting to consider on the basis of location of the egg in the oviduct as displayed in figure to. For the mitochondria values were highest when the oviduct did not contain an egg; for the microsomes the values were highest when an egg shell was being deposited.

Mitochondria have been suggested as having a functional role in the transcellular movement of ions by several investigators (THIERs et al., I960; VASINGTON and MurPhy, I962; PEACHEY, I964), and the evidence shown here indicates that the 
mitochondria of the shell gland participate in the movement of calcium. Microsomal fractions of muscle have been shown to accumulate calcium by an energy-dependent reaction (EBASHI and LIPMANN, I962; MolNAR and LORAND, I962), and it has been postulated that the endoplasmic reticulum, which is an important component of the microsomal fraction, is a mediator for the transport of calcium to and from the mitochondria (Cosmos, I964). Since the changes in ${ }^{45} \mathrm{Ca}$ levels of the microsomal fraction were opposite to those of the mitochondrial fraction it may be that ${ }^{45} \mathrm{Ca}$ is transitorily taken up by the mitochondria when shell calcification is not occurring and passed to the luminal portion of lining epithelium by these organelles and some component of the microsomal fraction when shell calcification is occurring. Confirmatory evidence with in vitro preparations is now in its preliminary stage (ELDER and SchraER, I969). A comparison was made on the uptake of ${ }^{45} \mathrm{Ca}$ by isolated mitochondria from the shell gland and liver of adult hens, and from liver and heart of a rat. The results thus far show that under in vitro conditions the shell gland mitochondria are still unique in their ability to accumulate calcium, taking up from four to three times as much ${ }^{45} \mathrm{Ca}$ over a 20 -minute period as hen and rat liver mitochondria and two to one and one-half times more than rat heart mitochondria.

The question of which cells of the mucosa contain the calcium hyperactive mitochondria is not answered by these experiments, but when considered with the results of the autoradiographic studies the view that these are the columnar cells is favored.

\section{ANION PRODUC'TION AND THE POSSIBLE ROLE OF CARBONIC ANHYDRASE}

In this brief survey of our recent work on calcium translocation we have thus far neglected to mention studies related to the carbonate counterion of the egg shell mineral. The significant role played by the bicarbonate ion and the mechanisms of its production and control have been discussed by my colleagues here, and in previous reports (MONGIN, I968).

In an effort to investigate the possible catalytic role of the enzyme, carbonic anhydrase, we have carried out cell fractionation studies of the shell gland mucosa (BERNSTEIN et al., I968). The presence and the distribution of the enzyme in cell fractions of the mucosal tissue was determined by a manometric assay (KREBs and Rough'Ton, I948). Data indicated that the enzyme is present in mucosal tissue and is primarily in a non-membrane associated state in the supernatant fraction. The activity of the mucosal enzyme was inhibited by sulfanilamide administered intramuscularly. Our findings were derived from a mixed cell population of mucosal tissue in which both the lining epithelial cells and the underlying tubular gland cells were represented. The histochemical findings of Draman'TSTEIN and Schi,UNS (I964) indicated that carbonic anhydrase is located in the cytoplasm of tubular gland cells. Our results coupled with the latter report lead to the conclusion that the enzyme is produced by the tubular gland cells and is probably not associated with membranes. Since the enzyme has also been detected in the fuid of the shell gland lumen at the time that a shell is mineralizing (BERNSTEIN and SCHRAER, I969), it is assumed that bicarbonate production occurs in the lumen. This does not eliminate the possibility that the enzyme may also act in the tubular gland cells. 


\section{CONCLUSIONS}

The non-destructive technique of quantitative radiography has clearly revealed the interrelationship of the skeletal mineral store and the formation of the egg shell. The nature of the reproductive cycle is reflected by the skeletal response to the demand for shell formation. In domestic hens that lay frequently the skeletal stores appear to be less than in poor layers. Pigeons which lay clutches of two eggs demonstrate a fall in skeletal mass during shell formation followed by an increase when shell formation has ceased. The domestic hen does not show such cyclic changes perhaps because of the relatively constant requirement for calcium in shell formation.

Experimental data concerning the individual molecular moieties that operate in the calcium translocation that occurs in the avian shell gland and the order of the metabolic scheme in which they operate is beginning to emerge. Calcium leaves the capillaries to travel primarily through the columnar epithelial cells of the mucosal lining of the gland. The unique calcium-binding capacity of the mitochondria in the mucosal cells appears to implicate these organelles in the metabolic sequence. That some phase of the translocation is energy-dependent has been established by transport studies. The presence of carbonic anhydrase in the tubular gland cells, in a nonmembrane attached form, and the recent detection of the enzyme in the fluid of the shell gland lumen indicate that bicarbonate may be catalytically formed in both the tubular gland cell and the shell gland lumen from the metabolic $\mathrm{CO}_{2}$ of the tubular gland cells and the columnar epithelial cells, respectively. In the case of the former site one would have to postulate the transfer of bicarbonate solutions from the tubular gland cells to the gland lumen via the gland cell ducts.

Whether the primary event in shell calcification is so simple as to depend on a control mechanism that first signals the active transport of calcium into the shell gland lumen, an event which is then followed by continual matrix production and the various processes necessary for the supply of the counterion, is impossible to state from present experimental findings.

The process is probably more complex than that described above. Additional information concerning the control mechanisms that operate on the cells of the shell gland during the production and transport of carbonate ions and the transport of calcium ions will be required before the process is completely understood.

\section{SUMMARY}

I. The skeletal response to the egg-laying cycle in the domestic hen and the pigeon was observed in vivo by quantitative radiography. Hens did not show cyclic changes in the tibio-tarsus mineral content while pigeons showed an increase in bone mass before ovulation and a decrease when egg shells were forming.

2. The shell gland of the hen did not contain large amounts of calcium; however, small but significant changes in tissue content of this metal occured when the egg was in different part of the oviduct. Calcium content was highest when an egg was in the infundibulum and lowest when an egg was in the isthmus.

3. Using an in vitro preparation it was shown that calcium movement across the shell gland is dependent in part on metabolic energy derived from oxidative metabolism and that such trans- 
location of metal requires the generation of phosphate-bond energy and is predetermined by the position of the egg in the oviduct when the animal was sacrificed. A potential of about $\mathrm{r}$ millivolt was found to exist across the shell gland in vitro with the mucosal surface always negative. The small potential could not account for the magnitude of the calcium flux in the mucosal direction and indicated that an active transport mechanism exists.

4. Autoradiography showed that the lining epithelium which accumulates significantly more ${ }^{45} \mathrm{Ca}$ than the tubular glands both in vivo and in vitro is probably most active in secreting calcium.

5. The mitochondria of the shell gland mucosa have an unusually high affinity for calcium both in vivo and in vitro when compared to mitochondria from other tissues.

6. The enzyme carbonic anhydrase was found to be primarily in a non-membrane associated state in the supernatant fraction of the mucosa and has been detected in the shell gland fluid.

The authors concluded that calcium is actively transported across the shell gland mucosa primarily through the lining epithelium. The mitochondria play an important role in this process. Carbonic anhydrase is located primarily in the tubular gland cells in a non-membrane associated form and is also present in the shell gland lumen. Bicarbonate is probably formed in both the tubular gland cells and the shell gland lumen from metabolic $\mathrm{CO}_{2}$ of the tubular glands and the lining epithelium.

\section{RÉSUMÉ}

\section{TRANSFERT DU CALCIUM A TRAVERS LA GLANDE COQUILLIÈRF}

I. Les modifications squelettiques durant le cycle de ponte de la poule domestique et du pigeon ont été étudiées in vivo par radiographie quantitative.

On n'observe aucun changement cyclique du contenu minéral du tibia et du tarse de la poule par contre la masse osseuse du pigeon s'accroît avant l'ovulation et diminue quand la coquille de l'œuf est formée.

2. La glande coquillière (utérus) des poules ne contient pas de grandes quantités de calcium; pourtant des modifications petites mais significatives du contenu tissulaire en cet élément se produisent quand l'œuf parcourt les différentes parties de l'oviducte. La teneur en calcium est la plus élevée quand un cuf est dans l'infundibulum et la plus basse quand il est dans l'isthme.

3. In vitvo les mouvements de calcium à travers la muqueuse utérine dépendent en partie de l'énergie métabolique provenant du métabolisme oxydatif. Un tel transfert nécessite la formation de liaisons phosphates riches en énergie et est prédéterminé par la position de l'œuf dans l'oviducte quand l'animal est sacrifié. Un potentiel d'environ $\mathrm{I} \mathrm{mV}$ existe à travers l'utérus in vitro avec la surface muqueuse toujours négative; ce faible potentiel ne peut pas expliquer l'importance du flux calcique vers la muqueuse et indique qu'un transfert actif existe.

4. Des autoradiographies montrent que l'épithélium columnaire qui accumule plus de $\mathrm{Ca}^{45}$ que les glandes tubulaires à la fois in vivo et in vitro est probablement plus actif dans la sécrétion de calcium.

5. Les mitochondries de la muqueuse utérine ont une affinité plus grande pour le calcium à la fois in vivo et in vitro que celles des autres tissus.

6. L'anhydrase carbonique est essentiellement dans la fraction surnageante de la muqueuse et a été détectée dans le fluide utérin.

Les auteurs concluent que le calcium est activement transporté à travers la muqueuse utérine essentiellement à travers l'épithélium columnaire et que les mitochondries jouent un rôle important dans ce processus. L'anhydrase carbonique est localisée dans les cellules des glandes tubulaires et non liée aux membranes; elle est également présente dans le fluide utérin. Les bicarbonates sont probablement formés à la fois dans les glandes tubulaires et le fluide utérin à partir du $\mathrm{CO}_{2} \mathrm{méta}^{-}$ bolique des glandes tubulaires et de l'épithélium columnaire.

\section{REFERENCES}

Bernstein R. S., Nevalainen T., Schraer R., Schraer H., I968. Intracellular distribution and role of carbonic anhydrase in the avian (Gallus domesticus) shell gland mucosa. Biochim. Biophys. Acta, 159, 367-376. 
Bernstein R. S., Schraer R., I969. Carbonic anhydrase and other proteins in the secretions of the avian shell gland. Unpublished data.

Bloom M. A., Domm L. V., Nalbandov A. V., Bloom W., I958. Medullary bone of laying chickens Amer. J. Anat, 102, 4II-553.

Cosmos $\mathrm{E}$., r 964 . Intracellular distribution of calcium in developing breast muscle of normal and dystrophic chickens. J. Cell Biol., 23, 24I-252.

Diamantstein T., Schluns J., ig64. Lokalisation und Bedeutung der Karboanhydrase im uterus von Legenhennen. Acta Histochem., 19, 296-302.

Ebashi S., Lipmann $\mathrm{F}^{\mathrm{s}}$., 196z. Adenosine triphosphate-linked concentration of calcium ions in a particulate fraction of rabbit muscle. J. Cell. Biol., 14, 389-400.

Ehrenspeck G., Schraer H., Schraer R., I967. Some metabolic aspects of calcium movement across the isolated avian shell gland. Proc. Soc. Exp. Biol. Med., 126, 392-395.

Ehrenspeck G., Schraer H., 1968. Calcium movement across the isolated avian shell gland. Fed. Proc., 2\%, 702 A.

Eldier J. A., Schraer H., Ig69. Calcium uptake by mitochondria from the avian shell gland. Unpublished data.

FEDER N., Sidman R. L., I958. Methods and principles of fixation by freezesubstitution. J. Biophys Biochem. Cytol, 4, 593-602.

Gay C. V., Schraer H., I967. Autoradiographic localization of calcium ${ }^{45}$ in the shell gland mucosa of the hen. Fed. Proc., 26, 660 A.

GaY C. V., Schraer H., I969. Autoradiographic localization of calcium in the mucosal cells of the avian oviduct. Unpublished data.

Hohman W., Schraer H., I966. The intracellular distribution of calcium in the mucosa of the avian shell gland. J. Cell Biol., 30, 3r7-331.

Hurwitz S., Griminger P., ig6o. Observations on the calcium balance of laying hens. $J$. $A g r$. Science, 54, 373-377.

Krebs H. A., Roughton F. J. W., I 948 . Carbonic anhydrase as a tool in studying the mechanism of reactions involving $\mathrm{H}_{2} \mathrm{CO}_{3}, \mathrm{CO}_{2}$ or $\mathrm{HCO}_{3}^{-}$. Biochem. J., 43, 550-555.

Kres P., Potter 'T. S., r934. Physiological marrow ossification in femalc pigeons, Anat. Rec,, 60, $377-379$.

Maxi T, Keilin D., I940. Sulfanilamide as a specific inhibitor of carbonic anhydrase. Natuve, 146, I $64-$ - 65 .

IICDOnald M. R., Ridibe O., I945. The effect of reproduction and estrogen administration on the partition of calcium, phosphorus, and nitrogen in pigeon plasma. J. Biol. Chem., 159, 445-467.

Misra M. S., Keufrer A., Ig64. Studies on the oviduct and serum of fowls. I. Oxygen uptake, alkaline phosphatase activity, concentration of phosphorus, calcium and magnesium in adult Hungarian yellow hens. Acta Vet. Hung., 14, 387-397.

Molnar J., Lorand L., r962. A phosphoryl group acceptor attached to the microsomal fraction of inuscle. Arch. Biochem. Biophys., 98, 356-363.

Mongin P., r968. Role of acid-base balance in the physiology of egg shell formation. IVorld's Poultry Science J., 24, 200-230.

PEACieY L. D., r964. Electron microscopic observations on the accumulation of divalent cations in intramitochondrial granules. J. Cell Biol, 2), 95-1 I I.

Schicar H., ig66. In Wiedon (x. D., Nenanas IV. F., Jisisiss D. IV., Progress in Developinent of Methods in Bone Densitometry, NASA Sp-64, I I-20, Washingtinl, D). C.

Schraer H., Schrafr R., I96r. Bone mass change; in hens observed in vivo during the egg laying cycle. Experientia, 17, 255-256.

Schraer R., Schraer H., I965. Changes in metal distribution of the avian oviduct during the ovulation cycle. Proc. Soc. Fixp. Biol. Med., 119, 937-942.

TAYloR A. N., WASsermaN R. H., I965. A vitamin $\mathrm{D}_{3}$-dependent factor influencing calcium binding by homogenates of chick intestinal mucosa. Nature, 205, 248-2.50.

Tarlor T. G., Hertenend Is, 1960. Parallel distribution of calcium and citric acid in the oviduct of the hen. Nature, 18\%, $244^{-245}$.

Tiners R. E., Reynolus Ji. S., Vallee 13. L., I960. The effects of carbon tetrachloride poisoning on subcellular metal distribution in rat liver. J. Biol. Chom., 235, $2130-2133$.

Thires R. E., Vallee B. L., I957. Distribution of metals in subcellular fractions of rat liver. $J$. Biol. Chem, 226, 91 I-920.

VAsington I: D., Murpiry J. V., 1962. Cat ${ }^{++}$uptake by rat kidney mitochondria and its dependence on respiration and phosphorylation. J. Biol. Chem., 237, 2670-2677.

Ussixg H. H., ZTRAHN K., I95I. Active transport of sodium as a source of electric current in the short circuited isolated frog skin. Acta Physiol. Sicand., 23, r ro-r 27. 